Original article

UDC 629.5.06.001.2:621.643

doi: $10.24143 / 2073-1574-2021-4-17-26$

\title{
Solutions to enhance technology in the fabrication process and installation of marine pipelines
}

\author{
K. N. Sakhno ${ }^{1 凶}$, Do Tat Manh ${ }^{2}$ Bui Sy Hoang ${ }^{3}$, V. M. Tsaloev ${ }^{4}$, \\ Peyvand Ahmad Saadati ${ }^{5}$, F. A. Lapeko ${ }^{6}$, Vu Van Tuyen ${ }^{7}$ \\ 1, 5, ${ }^{6}$ Astrakhan State Technical University, \\ Astrakhan,Russia,k.sakhno@mail.ru凶 \\ ${ }^{2,3,7}$ Vietnam Maritime University, \\ Haiphong, Social Republic of Viet Nam \\ ${ }^{4}$ Sevastopol State University, \\ Sevastopol, Russia
}

\begin{abstract}
The article describes possible solutions of the problem connected with shortening shipbuilding construction time as well as reducing production costs. To reduce the total amount of labour involved in the manufacture and installation of ship piping systems, which is $20 \%$ compared to the total labour volume of shipbuilding, authors provide the research on the possibility of manufacturing straight pipe sections with permissible deviations in combination with free flanges, analysis of deviation compensation for pipelines through the use of straight pipe sections manufactured with permissible tolerance and proposing new theoretical solutions to improve manufacturing and installing ship piping systems. Introduction of these technologies contributes to reduction of cycles of building and decrease in labour-intensiveness of pipeline works when carrying out marine orders. The chart of modeling the system of pipelines is presented. A straight pipe manufactured with an allowable deflection on a flat support and a loose flange attached to the end of the welded pipe are shown. The scheme of a permissible deviation $\alpha$ at mounting the connections between pipes is considered. The possibility of assembling curved pipelines using straight pipe sections is described in detail. The compensation zone is illustrated using the rotation of two pairs of deflected straight pipes. A block diagram of the application of research results in manufacturing and mounting a pipeline system has been developed.
\end{abstract}

Keywords: pipelines, projection, manufacturing, mounting, technological process, ship systems, production of pipelines, installation of pipelines

For citation: Sakhno K. N., Do Tat Manh, Bui Sy Hoang, Tsaloev V. M., Peyvand Ahmad Saadati, Lapeko F. A., Vu Van Tuyen. Solutions to enhance technology in the fabrication process and installation of marine pipelines. Vestnik of Astrakhan State Technical University. Series: Marine Engineering and Technologies. 2021;4:17-26. (In Russ.) doi: 10.24143/2073-1574-2021-4-17-26.

Научная статья

\section{Решения по улучшению технологий в процессе изготовления и монтажа морских трубопроводов}

\author{
К. Н. Сахно ${ }^{1 凶}$, До Тат Мань ${ }^{2}$, Буй Ши Хоанг ${ }^{3}$, В. М. Цалоев ${ }^{4}$, \\ Пейванд Ахмад Саадати ${ }^{5}$ Ф. А. Лапеко ${ }^{6}$, Ву Ван Туен $^{7}$ \\ 1, 5, 6 Астраханский государственный технический университет, \\ Acтрахань, Россия, k.sakhno@mail.ru凶 \\ 2, 3, 7 Вьетнамский морской университет, \\ Хайфонг, Социиалистическая Республика Вьетнам \\ ${ }^{4}$ Севастопольский государственный университет, \\ Севастополь, Россия
}




\begin{abstract}
Аннотация. Рассматриваются возможные пути сокращения сроков строительства в судостроении, а также снижения производственных затрат. Для снижения общего количества трудозатрат при изготовлении и монтаже судовых трубопроводных систем (что составляет $20 \%$ от общего объема судостроительных работ) исследованы возможности изготовления прямых участков труб с допустимыми отклонениями со свободными фланцами, проанализированы компенсации отклонений трубопроводов за счет использования прямых участков труб, изготовленных с регламентируемым допуском, и представлены новые теоретические решения для улучшения производства и монтажа судовых трубопроводных систем. Внедрение этих технологий способствует сокращению сроков строительства и снижению трудоемкости трубопроводных работ при выполнении заказов. Представлена схема моделирования системы трубопроводов. Показаны прямая труба, выполненная с допустимым смещением на плоской опоре; свободный фланец, прикрепленный к концу сварной трубы. Рассматривается схема допустимого отклонения $\alpha$ при монтаже соединений между трубами. Подробно описана возможность сборки изогнутых трубопроводов с использованием прямых участков труб. Продемонстрирована зона компенсации при использовании вращения двух пар отклоненных прямых труб. Разработана блок-схема применения результатов исследований в процессе изготовления и монтажа трубопроводной системы.
\end{abstract}

Ключевые слова: трубопроводы, проектирование, изготовление, монтаж, технологический процесс, судовые системы, изготовление трубопроводов, монтаж трубопроводов

Для цитирования: Сахно К. Н., До Тат Мань, Буй Ши Хоанг, Цалоев В. М., Пейванд Ахмад Саадати, Лапеко Ф. А., Ву Ван Туен. Решения по улучшению технологий в процессе изготовления и монтажа морских трубопроводов // Вестник Астраханского государственного технического университета. Серия: Морская техника и технология. 2021. № 4. С. 17-26. doi: 10.24143/2073-1574-2021-4-17-26.

\title{
Introduction
}

Over the past 30 years, the total amount of labour involved in the manufacture and installation of ship piping systems has increased from 5\% to $10-20 \%$ compared to the total labour volume of shipbuilding [1]. Many pipeline installation operations are located on the critical line, thus directly affecting the overall progress of shipbuilding. Therefore, one of the important trends in the shipbuilding industry today is to increase production efficiency through the introduction of new technologies into the process of manufacturing and installing piping systems, thereby helping to shorten shipbuilding construction time as well as reduce production costs.

Currently, in the world, there have been many studies to improve the technology in the design and installation of ship piping systems [2-4]. However, the solutions have not yet completely met the needs of reality, the workload as well as the labour time related to the installation of the ship's pipeline system still accounts for a high proportion. In other words, there is still a technological gap between these stages, making the pipe system drawings from design to implementation always have errors that are difficult to overcome. Although the number of research works has been relatively large, many problems still exist in the process of manufacturing and installing ship piping systems, even at many shipyards, it is still applied. The methods are quite rudimentary, highly dependent on the skill of the craftsman. This requires research to develop more effective support tools to fill in the technological gaps in this process.

Stemming from that practical need, the author believes that it is necessary to focus on researching solutions to improve technology in the process of manufacturing and installing ship pipeline systems, building a mathematical model to support the process. The process of designing and installing the pipeline system in the direction of enhancing prefabricated pipes, minimizing the number of pipes that need to be pre-sized in the installation space on the ship. In this solution model, it is necessary to forecast and calculate the size deviation compensation area to compare with the deviation area that may occur, thereby making appropriate recommendations in the manufacture and installation of pipelines. The research results will be the premise to propose a new solution in the field of design and installation of ship piping systems, thereby helping to reduce labour costs and execution time of shipbuilding orders.

Research on the possibility of manufacturing straight pipe sections with permissible deviations in combination with free flanges

The proposed solution solves the problem mentioned above related to the need to perform at post-design stage, analyze the pipeline route according to technology and manufacturability without the 
need for on-site dimensioning. Directional analysis determines the conditions and the possibility of compensating for dimensional coordinates deviation in relation to the position of the components connected to the pipeline route, considering the tolerances of the pipe fabrication.

During the pipeline fabrication process, with the help of the machine platform (CGT-160, CGT-160M, flat platform) we can manufacture straight pipes with the allowable deviation at the connector (displacement straight pipe). According to this principle, the top and bottom faces of the pipe are always parallel to each other but will not be perpendicular to the axis of the pipe (Fig. 1). The angular deviation from the perpendicular direction is within the limits of the standard documents, here we take the standard of the Russian Federation [5,6]. Rotation of these tubes is possible during pipeline assembly which will probably eliminate actual deviations.

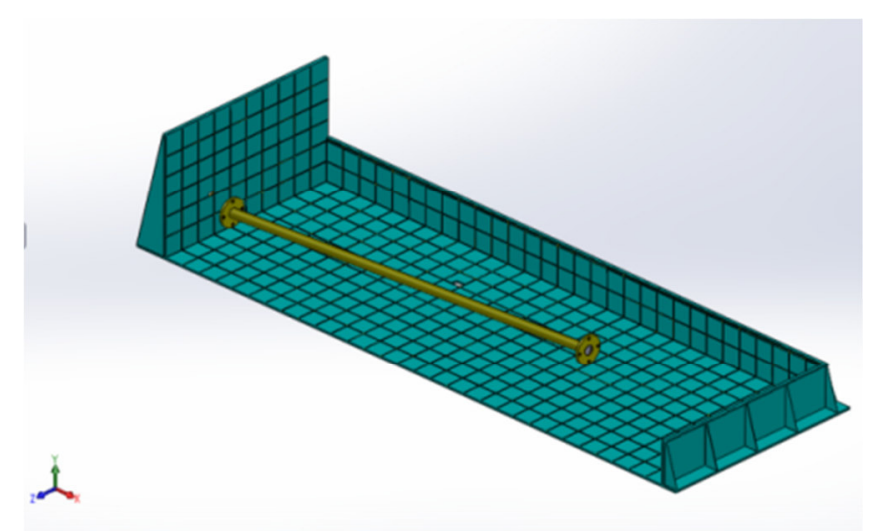

Fig. 1. Straight pipe made with permissible deflection on flat support

According to this method, the connector will be installed not perpendicular to the axis of the pipe. These deflection angles are specified in the respective standard documents. In the book OST industry standard 5.95057-90 of the Russian Federation, it is specified that the value of the limit deviation of the flange relative to the direction perpendicular to the axis of the pipe is according to the size of the diameter of the gasket of that pipe (Table).

The value of the limit deviation of the flange from the perpendicular to the pipe axis

\begin{tabular}{|c|c|}
\hline Condition diameter, $\mathbf{m m}$ & Limit deviation value of flange from the perpendicular of pipe axis, mm \\
\hline Under 100 & 2,0 \\
\hline From 100 to 200 & 4,0 \\
\hline From 200 to 400 & 6,0 \\
\hline
\end{tabular}

In order to develop the technology of manufacturing and installing ship piping systems in the direction of no pre-measurement of dimensions in the field, it is indispensable for free flanges. The use of free flanges greatly reduces the load on pipe fabrication and assembly: no precision is required with flange holes with bolts, so the flanges can rotate freely to any angle (Fig. 2).

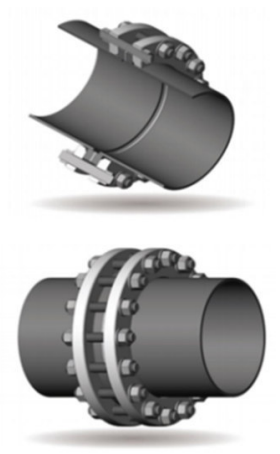

Fig. 2. Free flange attached to the end of the welded pipe 
Direct flange mounting to pipes with offsets shall be within the specified range of the standards.

The specific deviation when assembled at the connections between pipes should not exceed the values specified in the Standard with the corresponding parameters in Figure 3. The prospect of applying the results of this study is to use them in the design, manufacture and assembly of ship piping systems.

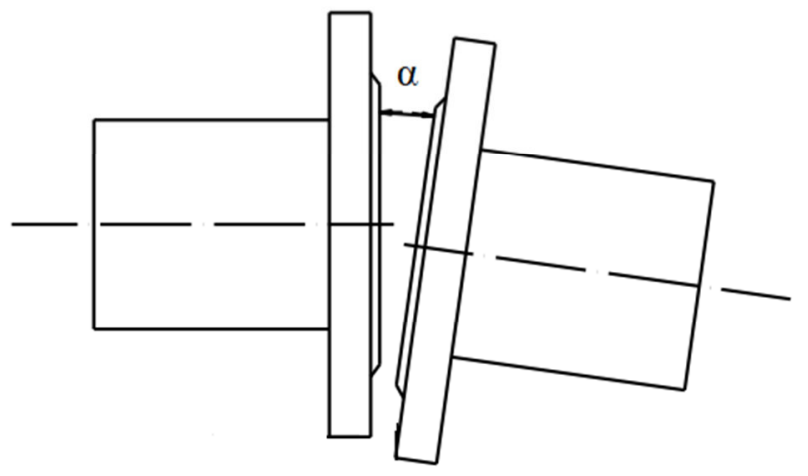

Fig. 3. Permissible deviation $\alpha$ when fitting connections between pipes

\section{Analysis of deviation compensation for pipelines through the use of straight pipe sections manufactured with permissible tolerances \\ Assembling ability of straight pipe sections in curved pipelines. \\ We consider a pipeline with the form shown in Figure 4, consisting of two straight pipes parallel to each other and two curved pipes. The offset for the pipeline will be done step by step.}

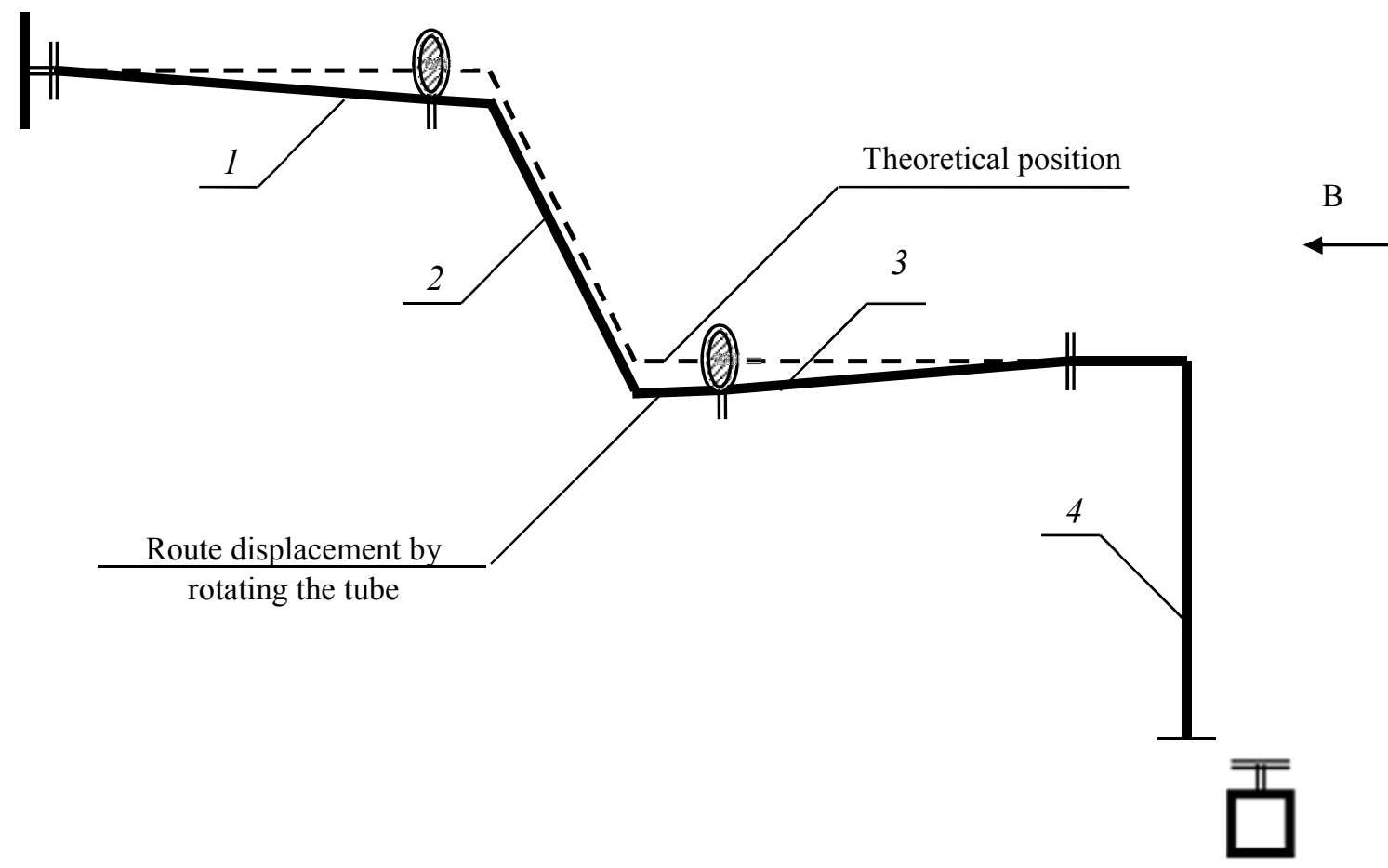

Fig. 4. Install the pipeline according to the theoretical state of the end pipe:

1,3 - straight pipe segments fabricated with allowable deviations; 2, 4 - curved pipe

The first step moves the route from the theoretical position through the application of straight pipe segments fabricated with allowable deviations 1 and 3 (Fig. 4). The corresponding state of the pipeline is located at position I in Figure 5. 


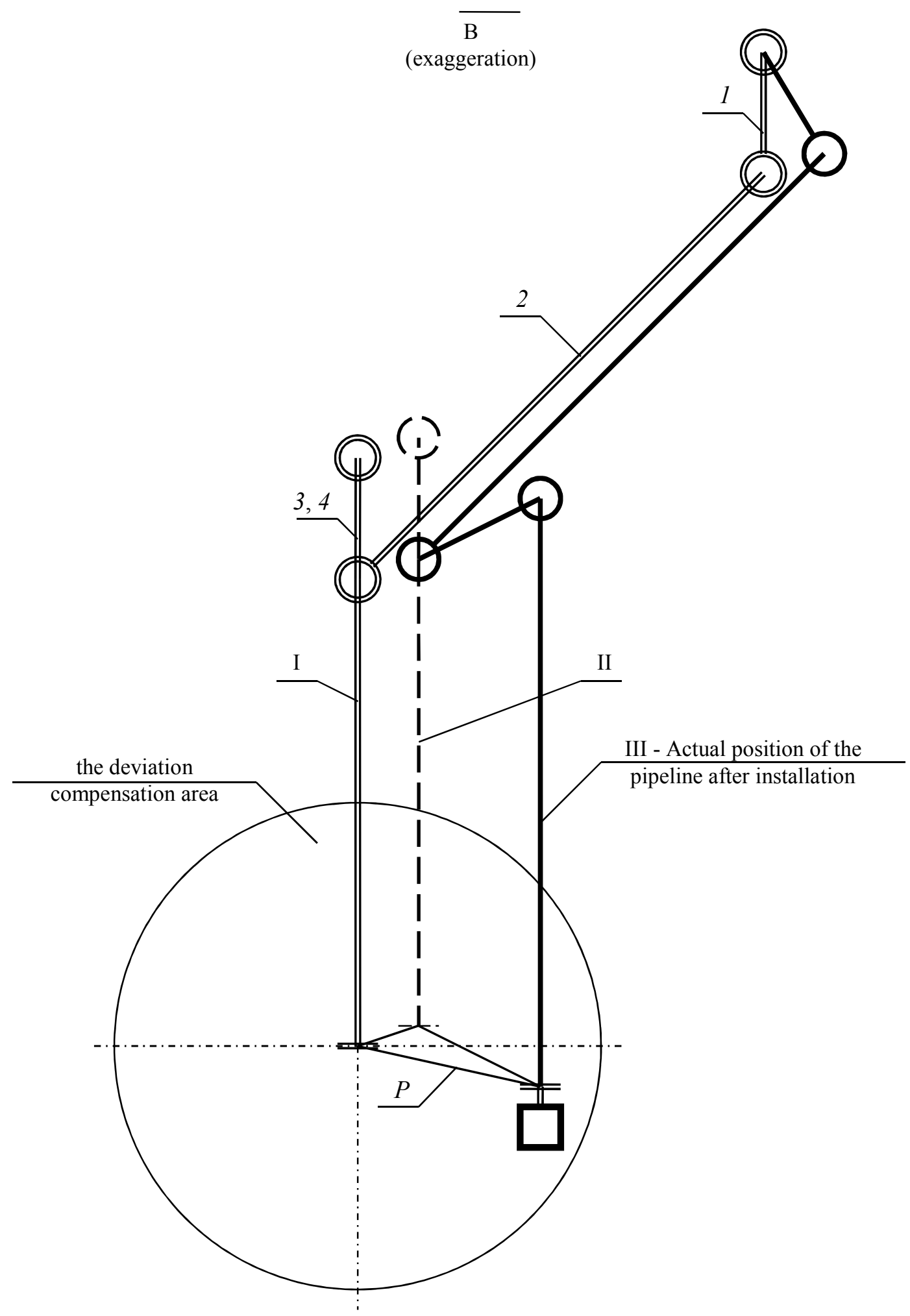

Fig. 5. Eliminating pipeline deviation by using two parallel straight lines: 1,3 - straight pipe segments fabricated with allowable deviations; 2, 4 - curved pipe; $P$ - deviation between the theoretical state and the actual state of the end point to be connected to the pipeline; I - the state of the pipeline after applying straight pipes made with permissible deviations 1 and 3 ; II - the state of the pipeline after turning the pipe 1 
In the second step, we proceed to remove the deviation of the position of the fixed connector limiting the pipeline $(P)$ by the following steps: Initially, we rotate the straight pipe 1 angle to move the pipeline to position II (Fig. 5). When rotating at the connection of pipe 1 care should be taken to control so that the direction of all components in the pipeline installed after pipe 1 is always parallel to their initial state.

At position II we continue to rotate the pipeline to the position to be reached (position III) through the rotation of the deviation pipe 3 . After turning pipe 3 a necessary angle value to compensate for the deviation should be noted to return to pipe 4 a corresponding angle, but in the opposite direction, then the last segment of the pipeline will reach the required position of the installation process that is the actual state of the pipeline (Fig. 5).

Thus, just with two straight pipe segments lying in the pipeline, either parallel to each other, or on the same line, we can move the end point of the pipeline in two directions of the coordinate axis. Again, we specify the amount of machining residue that coincides with the direction of the straight pipe segments.

The condition to be able to completely compensate for deviation, without using a compensator tube, is that there should be 2 pairs of straight pipes lying not coaxially in the pipe (Fig. 6, 7).

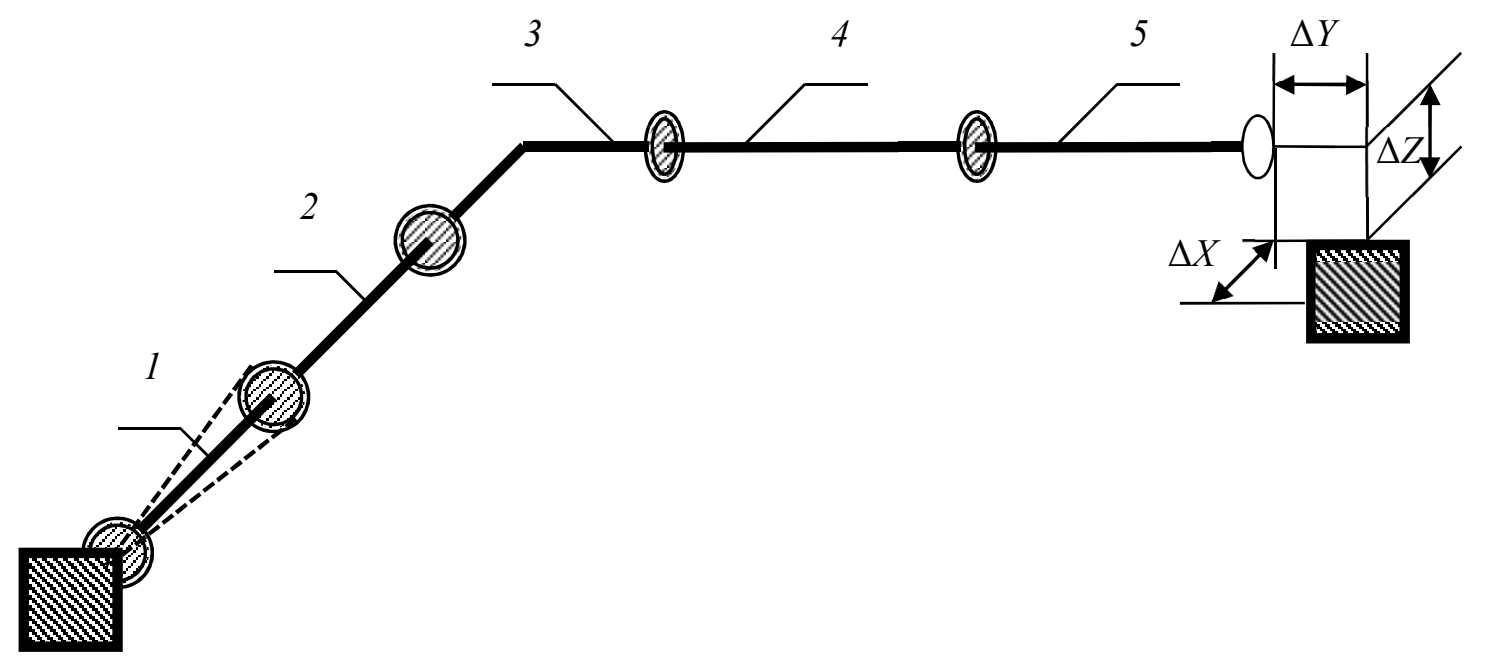

Fig. 6. Pipeline deviation compensation by two pairs of straight pipes:

$1,2,4,5$ - straight pipe segments fabricated with allowable deviations; 3 - curved pipe

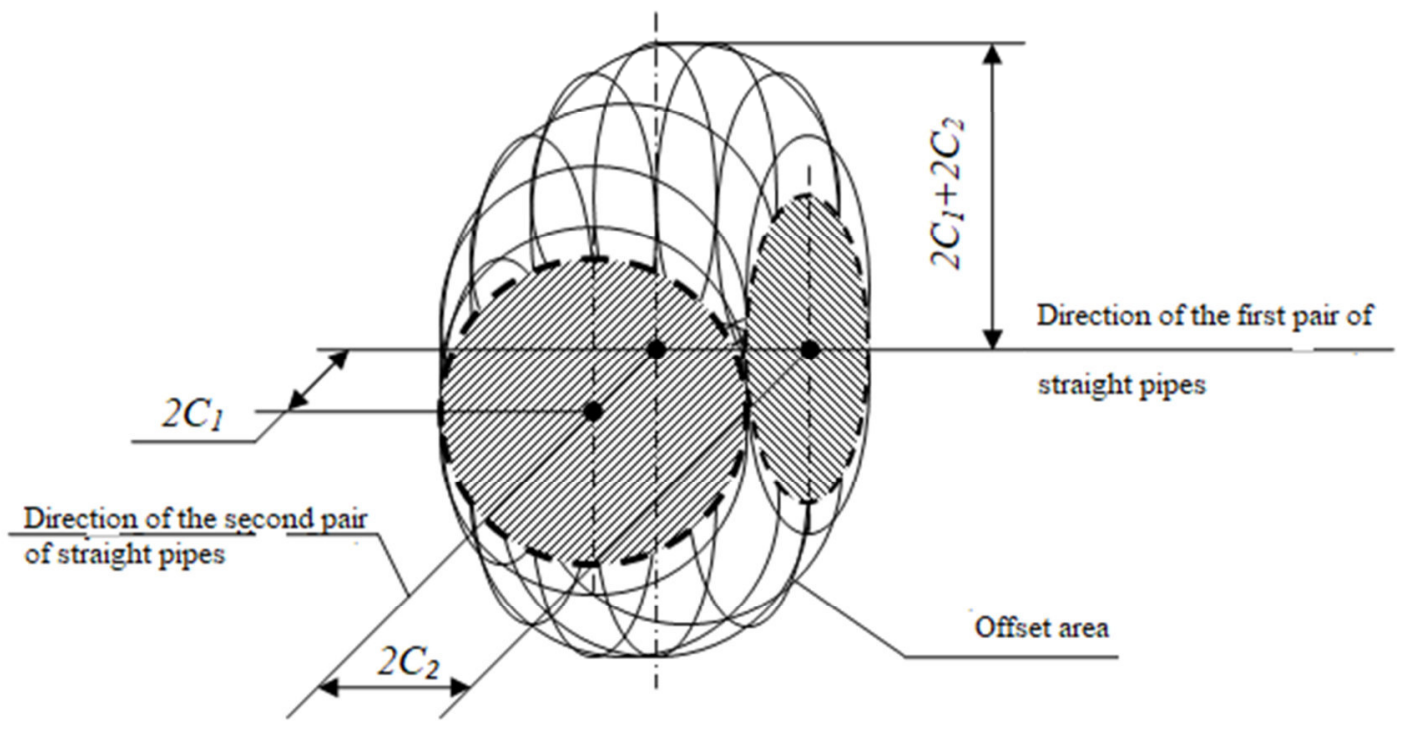

Fig. 7. Compensation area when using rotation of two pairs of deviated straight pipes 
To eliminate the deviation $\Delta Z$, we rotate the second pair of straight pipes, pipes 4 and 5 (Fig. 6). As a result, the pipeline will move to the position required for assembly while preserving the required orientation of the end of the pipeline. The compensation area of each pair of straight pipes is the plane bounded by a circle whose diameter is equal to the sum of the displacements of the pair of straight pipes.

To create a block offset it is necessary to use a consecutive combination of two planar offsets (Fig. 7).

\section{Proposing solutions for manufacturing and installing ship piping systems in the direction of not pre-measurement of dimensions at the field}

The traditional technology of performing the fabrication and assembly of the ship's piping system in separate areas of the ship $[2,7,8]$, will typically be implemented in the following steps:

1. Pre-assembly of manufactured pipes;

2. Adjustment of connections of compensating pipes on board, or in the presence of specialized machines at the plant;

3. Complete fabrication of compensating pipes at the factory (welding assigned joints, chemical treatment);

4. Assembling the compensating tubes;

5. Pressure test for the pipeline system.

Through the preliminary study of the possibility of compensating for deviation for the pipeline by rotating pairs of straight pipes in the pipeline, it is possible to design all the pipes in the pipeline from the beginning without having to measure the dimensions in advance scene. According to this proposed solution, the works to be carried out on the construction site will take place in 2 stages: $1+2$ and $4+5$, because the fabrication of the compensating pipes will be done at the same time as the construction process. prefabricated general pipelines, thereby allowing them to be bent at each individual route at the final stage of the main pipeline assembly. The interruption time between the two construction stages will be significantly reduced because we have reduced step 3 in the pipe fabrication process. Thus, by reducing the amount of labor associated with pipelines, this approach will set the stage to help shorten shipbuilding time.

According to the analysis shown above, we can see that it is possible to study and build a new technological solution to support the installation of pipelines, taking into account the design characteristics of the pipeline system of the ship's pipeline system. The set-up method is applied at the post-design, technical-technological preparation stage for pipelines and their installation, including:

- the method of determining the possibility of laying the pipeline and the meaning of the technological residue indicated at the end of the correction pipes;

- technology of manufacturing and installing pipes according to design information combined with the application of rotation of straight pipes manufactured with permissible deviations at the connections.

Once the automatic analysis system is built, the technology-oriented route analysis will be specified after the preliminary routing of the pipeline route and division of the route into branched pipes and joints (Fig. 8).

The activities in the dashed section are the actions that the author proposes to add in the pipeline system design and installation process. Implementing this process will help improve the technology, ensure the accuracy in the actual construction and installation of the ship's pipeline system.

\section{Conclusion}

The establishment of new theoretical and methodological solutions mentioned above will help improve the pipeline technology on the basis of geometric prototyping and the deflection compensation of the pipeline. These solutions will eliminate the need for on-site dimensioning, saving construction time and labour efforts in the piping section when fulfilling shipbuilding orders, as well as increasing efficiency of workers in the shipyards. 


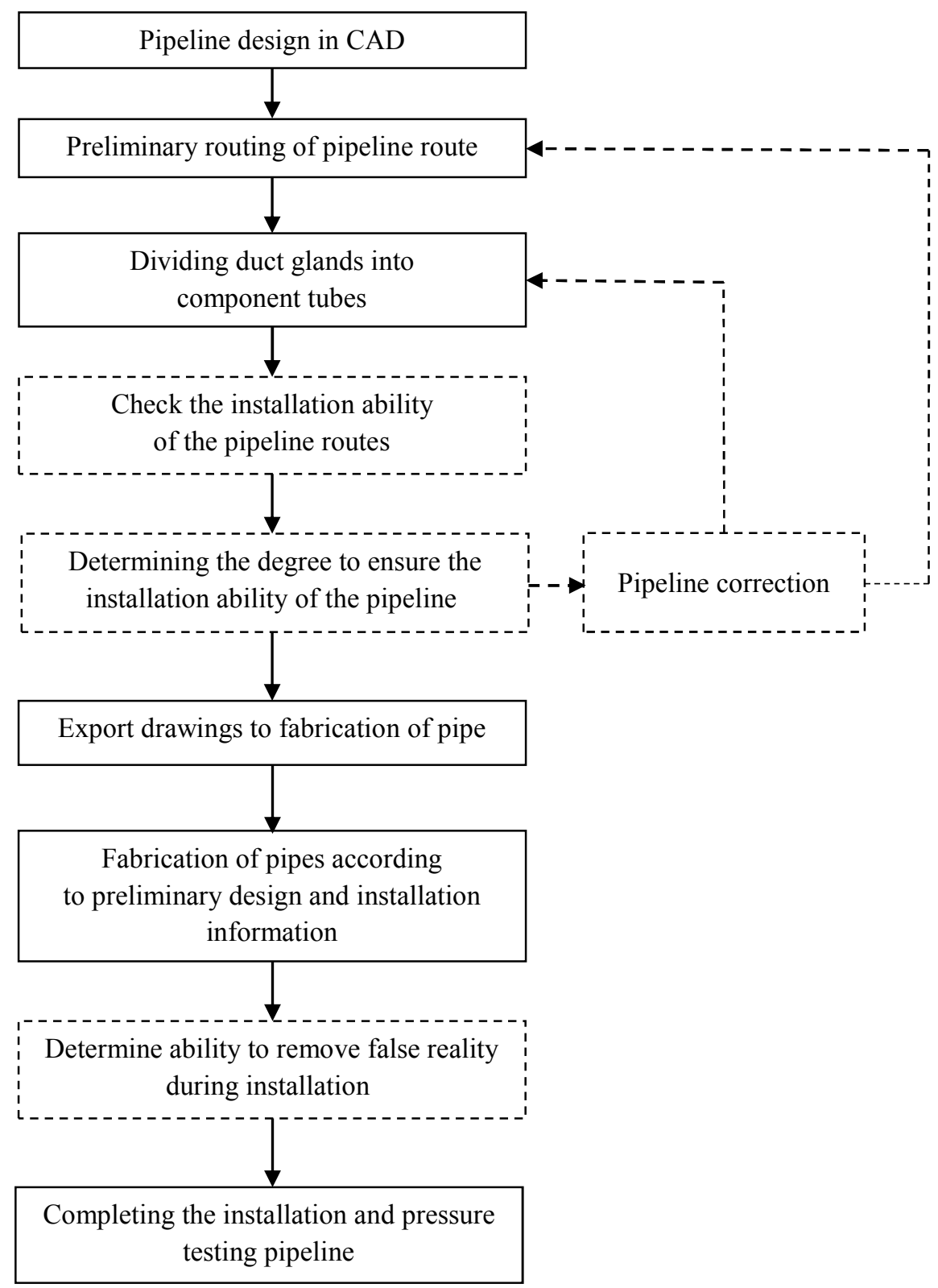

Fig. 8. Flowchart of applying the research results in manufacturing and installing the pipeline system

\section{REFERENCES}

1. Sakhno K. N. Nauchnye osnovy povysheniya tekhnologichnosti tpuboprovodov sudovykh sistem na stadii proektirovaniya: dis. ... d-ra tekhn. nauk [Scientific grounds for improving technical performance of pipelines of ship systems at stage of design: diss. ... dr. tech. sci.]. Astrakhan', 2012. $270 \mathrm{p}$.

2. Gopelik B. A. Sposob sborki trubnogo soedineniya [Assembly method for tube connections]. Sudostroenie, 2002, no. 3, pp. 26-27.

3. Liu Q. A., Jiao G. Pipe Routing Method Considering Vibration for Aero-engine using Kriging Model and NSGA-II. IEEE Access, 2018, vol. 11, no. 3, p. 6. DOI: 10.1109/ACCESS.2018.2789361.

4. Safa M., Shahi A., Nahangi M., Haas C., Noori H. Automating measurement process to improve qualitu management for piping fabrication. Structures, 2015, vol. 3, pp. 71-80. DOI: 10.1016/j.istruc.2015.03.003.

5. GOST 4433-76. Flantsy apmatury, soedinitel'nykh chastei i truboprovodov sudovye. Tipy [GOST 443376. Flanges for fittings, connecting parts and ship pipes. Types]. Moscow, Izd-vo standartov, 1998. 7 p.

6. OST 5.95057-90. Sistemy sudovye i sistemy sudovykh energeticheskikh ustanovok. Tipovoy tekhnologicheskiy protsess izgotovleniya i montazha tpuboprovodov [OST 5.95057-90. Systems of ships and systems of ship power plants. Typical technical process for manufacturing and mounting pipelines]. Leningrad, RTP NPO «Ritm», 1990. $201 \mathrm{p}$. 
7. Dang Van Tuan. Curriculum plumber Shipbuilding. Vietnam Maritime University, Hai Phong, 2005. 68 p.

8. Le Loc. Pipe Shipbuilding. Transportation Publisher, 2011. 359 p.

\section{СПИСОК ИСТОЧНИКОВ}

1. Сахно K. Н. Научные основы повышения технологичности трубопроводов судовых систем на стадии проектирования: дис. ... д-ра техн. наук. Астрахань, 2012. 270 с.

2. Горелик Б. А. Способ сборки трубного соединения // Судостроение. 2002. № 3. С. $26-27$.

3. Liu Q. A., Jiao G. Pipe Routing Method Considering Vibration for Aero-engine using Kriging Model and NSGA-II // IEEE Access. 2018. Vol. 11. N. 3. P. 6. DOI: 10.1109/ACCESS.2018.2789361.

4. Safa M., Shahi A., Nahangi M., Haas C., Noori H. Automating measurement process to improve quality management for piping fabrication // Structures. 2015. Vol. 3. P. 71-80. DOI: 10.1016/j.istruc.2015.03.003.

5. ГОСТ 4433-76. Фланцы арматуры, соединительных частей и трубопроводов судовые. Типы. М.: Изд-во стандартов, 1998. 7 с.

6. ОСТ 5.95057-90. Системы судовые и системы судовых энергетических установок. Типовой технологический процесс изготовления и монтажа трубопроводов. Ленинград: РТП НПО «Ритм», 1990. 201 с.

7. Dang Van Tuan. Curriculum plumber Shipbuilding. Vietnam Maritime University, Hai Phong, 2005. 68 p.

8. Le Loc. Pipe Shipbuilding. Transportation Publisher, 2011. 359 p.

Статья поступила в редакцию 01.10.2021; одобрена после рецензирования 27.10.2021; принята к публикации 08.11.2021. The article was submitted 01.10.2021; approved after reviewing 27.10.2021; accepted for publication 08.11.2021.

\section{INFORMATION ABOUT THE AUTHORS}

Konstantin N. Sakhno - Doctor of Technical Sciences, Professor; Head of the Department of Shipbuilding and Power Complexes of Marine Equipment; Astrakhan State Technical University; 414056, Astrakhan, Tatishcheva St., 16; k.sakhno@mail.ru

Do Tat Manh - Candidate of Technical Sciences; Lecturer of the Institute of Postgraduate Education; Vietnam Maritime University; Haiphong, Social Republic of Viet Nam; dotatmanh@vimaru.edu.vn

Bui Sy Hoang - Master's Course Student; Lecturer of the Faculty of Shipbuilding Technology; Vietnam Maritime University; Haiphong, Social Republic of Viet Nam; buisyhoang@gmail.com

Vladimir M. Tsaloev - Assistant Professor of the Department of Shipbuilding and Power Complexes of Marine Equipment; Sevastopol State University; 299053, Sevastopol, Universitetskaya St., 33; orcid.org/0000-0002-1947-3081;1.@mail.ru

Peyvand Ahmad Saadati - Assistant of the Department of Technological Machines and Equipment; Astrakhan State Technical University; 414056, Astrakhan, Tatishcheva St., 16; peyvand@inbox.ru

Fedor A. Lapeko - Postgraduate Student of the Department of Shipbuilding and Power Complexes of Marine Equipment; Astrakhan State Technical University; 414056, Astrakhan, Tatishcheva St., 16; strax30rus@gmail.com

Vu Van Tuyen - PhD.; Lecturer of the Faculty of Shipbuilding Technology; Vietnam Maritime University; Haiphong, Social Republic of Viet Nam; tuyenvv.dt@vimaru.edu.vn

\section{ИНФОРМАЦИЯ ОБ АВТОРАХ}

Константин Николаевич Сахно - доктор технических наук, профессор; заведующий кафедрой судостроения и энергетических комплексов морской техники; Астраханский государственный технический университет; 414056, Астрахань, ул. Татищева, 16; k.sakhno@mail.ru 
До Tam Мань - кандидат технических наук; преподаватель института последипломного образования; Вьетнамский морской университет; Хайфонг, Социалистическая Республика Вьетнам; dotatmanh@vimaru.edu.vn

Буй Ши Хоанг - магистр; преподаватель факультета судостроения; Вьетнамский морской университет; Хайфонг, Социалистическая Республика Вьетнам; buisyhoang@gmail.com

Владимир Муратович Цалоев - доцент кафедры судового электрооборудования; Севастопольский государственный университет; 299053, Севастополь, ул. Университетская, 33; orcid.org/0000-0002-1947-3081; 1._@mail.ru

Пейванд Ахмад Саaдати - ассистент кафедры технологических машин и оборудования; Астраханский государственный технический университет, 414056, Астрахань, ул. Татищева, 16; peyvand@inbox.ru

Федор Александрович Лапеко - аспирант кафедры судостроения и энергетических комплексов морской техники; Астраханский государственный технический университет; 414056, Астрахань, ул. Татищева, 16; strax30rus@gmail.com

Bע Baн Tyeн - кандидат технических наук; преподаватель факультета судостроения; Вьетнамский морской университет; Хайфонг, Социалистическая Республика Вьетнам; tuyenvv.dt@vimaru.edu.vn 